\title{
The Relationship between Human Being and Animal: The Study of the Concepts of Khalifah and the Animals in the Quran
}

\author{
Lis Safitri, Muhammad Nuskhi, Krismiwati Muatip, Hermin Purwaningsih, and Lucie Setiana \\ Faculty of Animal Science, Universitas Jenderal Soedirman, Purwokerto, Central Java, Indonesia \\ *Corresponding author e-mail: lis.safitri@unsoed.ac.id
}

\begin{abstract}
Islam does not only talk about the procedure of worshiping (ibadah), but also related to daily activities (muammalah), including how to treat animals. Understanding the relationship between human being and animals is the basis for further studies of animals in Islam. This study is library research using the descriptiveinferential method with the purpose to elaborate on the position of the animal against the human being based on the concept of the human being as khalifah. The Quranic verses about khalifah and animals in the Quran have been collected using thematic interpretation method of al-Farmawi. The data have been analyzed using philosophical and theological approaches to find the concept of khalifah and the position and the purpose of animal life in the Quran. The result showed that God gives rightful supremacy on earth to human beings for upholding God's law and guiding the creatures to their purpose of creation, because of their blessed potentials i.e. emotion, intelligence, and natural disposition for grasping the truth and goodness (fitra). Human being has to treat animals in line with the objective of their creation, i.e. God's creature, the Signs of God's Power, viands for human being and the other creatures, ride, and the lesson of life.
\end{abstract}

Key words: Human being; khalifah; the objective of creation; animal; Quran

\begin{abstract}
Abstrak. Islam tidak hanya membahas tentang tata cara ibadah, melainkan hal-hal yang berkaitan dengan kehidupan sehari-hari (muammalah), salah satunya tentang cara memperlakukan hewan. Pemahaman tentang hubungan antara manusia dengan hewan merupakan pengetahuan dasar yang harus diketahui sebelum beranjak pada kajian lain mengenai hewan menurut Islam. Penelitian ini merupakan penelitian kepustakaan dengan menggunakan metode deskriptif-inferensial, dengan tujuan untuk mengelaborasi posisi hewan bagi manusia berdasarkan konsep manusia sebagai khalifah. Penelitian ini menggunakan model tafsir tematik. Ayat-ayat alQuran yang berkaitan dengan hewan dikumpulkan dengan metode tafsir maudhu'l model al-Farmawi. Data dianalisis menggunakan pendekatan filosofis dan teologis untuk menjelaskan konsep khalifah dan posisi serta tujuan penciptaan hewan menurut al-Quran. Hasil penelitian menunjukkan bahwa Tuhan memberikan kuasa yang sah bagi manusia untuk menegakkan hukum Allah di muka bumi dan mengantarkan makhluk pada masingmasing tujuan penciptaannya, karena potensi yang dimiliki oleh manusia seperti emosi, akal, serta potensi dasar manusia yang selalu berusaha mencari kebaikan dan kebenaran (fitrah). Manusia harus memperlakukan hewan sebagaimana tujuan penciptaannya, yaitu sebagai makhluk, tanda kekuasaan Tuhan, rejeki bagi manusia dan makhluk lain, kendaraan, serta pelajaran hidup.
\end{abstract}

Kata kunci: manusia, khalifah; tujuan penciptaan makhluk; hewan; al-Quran

\section{Introduction}

The clash between religion and science has happened since a long time ago and resulted in a fierce debate between scientists and religious leader. Nowadays, the view on the relationship among them has already shifted. Some scholars argued that there was an ambivalent relationship between theology and science (Beed and Beed, 2010), and other scholars believe that both of them in need, strengthen each other, and provide mutual benefits (Janah, 2018).

Some Islamic scholars tried to dialect between Islam and science in a many ways, such as the knowledge integration based on perennial philosophy as practiced by Syed Hossen Nasr (Hidayatullah, 2018), Islamization of science as initiated by M. Naquib al-Attas (Novayani, 2017), scientification of Islam as practiced by Kuntowijoyo (Chaeruddin, 2016), the integration-interconnection of knowledge developed by $\mathrm{M}$. Amin Abdullah, and theistic science (Muslih, 2016). Whatever the form, the religious approach should be recognized as one of the fundamental things as moral teaching in understanding science, and because of science, the understanding of religion is more applicable and more comprehensive in solving the contemporary issues. 
The Islamic approach on livestock and animal science in Indonesia becomes noteworthy, considering the majority of Indonesian people are Muslim with farming as the main job. In 2017, the amount $31,9 \%$ of Indonesian peoples work as farmers, and $11,4 \%$ of them are in the livestock sector (Ditjen PKH, 2017). Other facts, the majority of Indonesian people are Muslims, but most of them are laypeople who didn't have a deeply religious understanding based on the Quran and Hadis practically.

This paper was written to provide a comprehensive explanation about the positions of the animal against the human being based on the concept of human duty as a khalifah (vicegerent of God or who inherit the earth) focus on the study of Quranic verses about khalifah and animals. This study was conducted based on two questions: how is the relationship between human beings as khalifah and animals regarding the positions of animals according to the Quran? What should human beings do in treating animals according to the Quran? This study is the basic research for further studies about livestock and animal science and treating the animal in daily life.

\section{Materials and Methods}

This research is library research using the descriptive-inferential method. The primary data are the Quranic verses about animals and human being position as vicegerent (khalifah). The verses was traced using a dictionary of the Quran entitled al-Mu'jam al-Mufahras li alfadz alQuran (Baqi, 2013), with an'am and dabbah as the keywords to search the verses talked about animals, and khalifah for the verses about vicegerent. The secondary data are the interpretations from Quran interpreters, both classical and contemporary interpreters, who have elucidated this theme very well. The verses are compiled using thematic interpretation method (tafsir maudhu'i) of al-Farmawi, and analyzed using philosophical and theological approaches.

\section{Results and Discussion}

\section{Human as Khalifah in the Quran}

Khalifah (pl. khalaif), derived from the verb khalafa, has five meanings: those who are behind, the one who stands behind the other and now in his/her position, the successor, the one who comes after, those who succeed another (Lajnah Pentashihan al-Quran, 2017b). Allegorically, this term is used to denote man's rightful supremacy on earth as a vicegerent of God to proceed with God's creation in the world ((Asad, 1984). Firstly, God created the universe and the creatures on it, then God gives man the rightful authorities to continue His creation by upholding God's messages (Surah Sad/38: 26), prospering the world, preventing it from damage (al-A'raf/7: 56), and guiding the creatures to the objective of its creation. Of course, it does not indicate God's incapability in performing $\mathrm{His}$ duties, but He appreciates human being's honors as the best creature (al-Tin/95: 4) and tempts them because of the gifts they received (alFurqan/25: 20) (Shihab, 2000a).



Figure 1 The circular relationship among human being's potentials

The enforcement of these messages of God does not only perform worshiping but also paying much attention to the surroundings, including human being, nature, animals, and the other creatures. Man's Human appointment as who inherit the earth has been narrated in surah al-Baqarah/2: 30, al-'Anam/6: 165, al-Naml/27: 62, dan Fatir/35: 39 because of their capabilities. Human beings are given some provisions, i.e. intelligence manifested in knowledge, emotions, and the natural disposition (fitrah) an intuitive ability to discern between right and wrong, true and false, and to incline toward the truth and the right state (Ali, 1998). The Figure 1 showed that these points have established an inseparable circular relationship associated with human deeds. The knowledge could not lead man to salvation by itself, but has been subdued natural 
disposition for grasping the truth and goodness. Thus, emotion is what distinguishes man from angels, full consciousness of the possibility or necessity of a moral choice. While the angels are the full compliance creatures, could not choose what they would do (Safitri, 2016).

At least, there are two words in the Quran dealing with animals, i.e. an'am and dabbah. An'am (al-Maidah/5: 1 and al-An'am/6: 136) is derived from noun na'm means a pleasant and good state. The Arabs are accustomed to using this word to mention camel as the symbol of the best food and the best ride, although many authors reckoned this word refers to cattle. Dabbah has a lighter and smoother meaning than walking. It refers to all of the kinds of animals (alAn'am/6: 38) and sometimes man (al-Nahl/16: 49 and Hud/11: 6) (Lajnah Pentashihan al-Quran, 2017a).

Through these words, the Quran provided a variety of narratives related to animals. First, animals are one of the signs of God's Power (alNur/24: 45, Fatir/35: 28, Yasin/36: 71, alSyura/42: 11 and 29, al-Jasiyah/45: 4, and alMulk/67: 19). For instance in surah al-Baqarah/2: $164 \mathrm{God}$ expressed that in the creation of the heavens and the earth, the succession of night and day, and the living of multiple creatures, there are messages indeed for who use their reason. People who studied animal science and comprehended God's messages in animal life, then improved their conscious of God could be called as "people who are endowed with insight" (ulul al-bab), one of the highest position of the human being in the Quran (Ali Imran/3: 190191). No wonder when God called them as the most conscious of the Divinity (Fatir/35: 28).

Second, animals are creatures like human beings (al-An'am/6: 38), but they are not given a perfect reason like a man (al-A'raf /7: 179). In surah al-An'am/6: 38, God likened human being and animal as umam (s. ummah, literally means a group of living being or community). This verse can be explained as, whether human beings and animals have the same characteristic of life from its inception until the end: from an embryo, be born, matured, getting old, then death, having a basic need such as consumption, safety, communication, etc. (Shihab, 2000c). As a creature of God, animals always obey His commands and provisions named sunatullah
(God's way), even some verses state that animals exalted (al-Saf/61: 1) and prostrated themselves (al-Hajj/22: 18) to God.

Third, animals are the sustenance for a human being (al-Ma idah/5: 1 and 96, al-Hajj/22: 34, al-Syu'ara/26: 133, al-Nahl/16: 14, Fatir/35: 12) except for the unlawful animals (alMa idah/5: 3, al-Nahl/16: 115). Besides that, animals can be used as ride or transportation (alAn'am/6: 142-146, Gafir/40: 79, al-Zukhruf/43: 12) and the other benefits such as milk (alNahl/16: 66, al-Mu'minun/23: 21), honey (alNahl/16: 69) and its leather, fur, or feather (al$\mathrm{Nahl} / 16: 5$ ). To make them lawful to be eaten, they have to be slaughtered in the name of God and kept its thayyib (goodness) aspect (alBaqarah/2: 173 dan al-Ma`idah/5: 4).

Fourth, sometimes the Quran used animal attitudes as an allegory of the bad behavior of human being. For instance, in surah alBaqarah/2: 65, al-Ma idah/5: 60 and al-A'raf/7: 166 the Quran narrated Bani Isra il who profaned the Sabbath then cursed became apes. Another animal that used in metaphorical allusion is a dog with his tongue lolling (al-A'raf/7: 177), to analogize people who could not manage their desires showing greedy in worldly things, so they could not separate their need from lust (Asad, 1984).

Fifth, the Quran narrated animal as the miracle of Prophet or the signs of God's Almighty, for example, the camel of Prophet Saleh (al-A'raf/7: 73-77 and Hud/11: 64-69) and the snake of Prophet Musa (Taha/20: 18). The other animals perpetuated in the Quran are the cow that has awaken a corpse after Bani Isra il accused each other about who is the murderer (al-Baqarah/2:67-71) and the revived horse from the bones with the whole community in the village (al-Baqarah/2: 259).

Sixth, the Quran recounted a couples stories about the good behavior of animals as the lesson for man. The famous story of the guardian dog who faithfully protected and accompanied the sleeper in the cave (ashabul kahfi) for thousands years and the story about Qabil, son of Adam, who killed his brother has been inspired to bury the corpse of his brother after seeing a crow buried his opponent fight (al-Ma`idah/5: 31).

Seventh, the animal is one of man's pride (Ali 'Imran/3: 14 and al-Nahl/16: 8). Man has 
passions and desires as a basic disposition. Surah Ali Imran/3: 14 explained that man has enjoyment through women, children, treasures, and horses, cattle, and lands. All of that can be enjoyed as long as make her/him is grateful to God.

Eight, harming animal and offering animal for the other God except Allah is a condemned act (al-Nisa '/4: 119 and al-An'am/6: 136). Al-Nisa '/4: 119 expressed the habit of pre-Islamic Arabs in harming animal by ear-cutting, eyes-blinding, face-tattoo to offer an animal for idolatrous sacrifice. The animal was not killed but left alive after being scratched or cut. It is prohibited, not only because of harming animal but also placing an animal for idolatrous.

Ninth, animal used to punish faithless people. Surah al-A'raf/7: 130-133 God tormented Pharaoh and his people with a drought, hurricane, pest attack such as locusts, lice, and frogs until they were starving because of the scarcity of fruits. This disaster is happened to be a lesson, but they claimed every comfortable life was the result of their efforts, while every adversity was Musa as. and Harun as. heresy.

\section{The Relationship between Human Being and Animal according to the Quran}

The main role of a human being is an 'abd or servant (al-Zariyat/51: 56) and vicegerent or khalifah. Man as who inherit the earth means prolong of the "hand" of God to guide the creatures to the objective of its creation. God respects human beings to manage the earth because of their abilities because of some provision blessed to them, i.e. emotion as the basic provision in making a decision, intelligence manifested in knowledge, and the natural disposition (fitrah) an intuitive will to incline toward the truth and the right state.

Associated with the term of khalifah, al-Shadr mentioned three points related with it, i.e. the human being themselves as vicegerent, the world (especially earth) as the place of duty, and the relationship among human being, the world, and the creatures on it (Shihab, 2006). The third point is implemented as the duty in guiding all of the creatures to the objective of their creation. Here are some purpose of animal creation narrated in the Quran, 1) animals are created as creatures like human being, flora, mount, earth, universe, etc. 2) animals are created as the signs of God's power, 3) animals are the viands, medicine, clothing, and the other benefit to support human being's life 4) transportation or ride as the God's blessing for human being, and 5) the lesson for better life.

Khalifah has to be able to guide the animals to the aim of their creation. If the animals have not treated in line with their aim of life, men have not been able to complete their duties as a khalifah. The men who did not fulfill their perfection of life are not different from an animal, even more astray (al-A'raf/7: 179). God has only given them the instinct to avoid the danger, seeking food, reproduce, etc. It is reasonable if their life is limited to the basic behavior, they did not have abilities in analogizing mind and producing knowledge that made their act wiser than others. When someone was unable to decide a wise behavior, he deserves to be blasphemed because worse than animals.

Glorifying animal or placing them as an idolatrous sacrifice is contrary to the objective of the animal creation as creatures, not khaliq (creator). Killing animals at a young age that has not reached the limits of reasonableness to be slaughtered (unless there is a good reason) is prohibited because animals can be taken as viands for human consumption required the concept halal (lawful) as well as thayyib (good condition). Thayyib is a good and proportionate food condition, that is not only considered from the consumer sight but also animal worthiness. Torturing animals can't be accepted as khalifah's behavior. It is discord with the concept of equal position between man and animal as God's creatures, who should respect each other. The last, animals could not be regarded as guidance to understand the events of life. Man can only learn their life as life lessons (Shihab, 2000b).

Performing their duties as vicegerent, human beings have to consider some circumscriptions related to animal preservation. First, any kinds of animal-damaging acts are not allowed (al-Rum / 30: 41). Human beings with their great potentials should protect animal welfare and treat animals proportionally to honor their creator. Second, in some verses, God reminds man that in the creation of animals there are many signs of God's power to be learned for strengthening belief in 
God and the wisdom of life (al-Rum/30: 41). Third, exploiting animals should not be excessive (al-A'raf/7: 31), extravagance (al-Isra'/17: 16), and futility (al-Isra`17: 27) that would ruin the animal habitats, animals conditions, population alignment, and human beings themselves(Lajnah Pentashihan al-Quran, 2017a).

\section{Conclusions}

The Qur'an considered that the relationship between human beings and animals is mutual. Animals are the fortune for human beings to reach their goal as khalifah or the vicegerent of God. Also, one of the tasks of khalifah is also to guide animals to the purpose of their creation. They can only be treated in the realm of the purpose of creation, includes 1) animals are created as creatures of God, 2) animals are the signs of God's power, 3 ) animals are the gift, 4) animals are the lesson for human's better life. The Qur'an sets the limits in treating them: 1 ) man can't treat animals beyond the limits the purpose of their creation, 2) any kinds of animaldamaging acts are not allowed, 3) man should learn the various aspects of animal life for strengthening belief in God and the wisdom of life, 4) exploiting animals should not be excessive, extravagance, and futility.

\section{References}

Ali, A. Y. (1998) The Holy Quran.pdf. New York: Elmhurst.

Asad, M. (1984) The Message of The Quran. Gibraltar: Dar al-Andalus. doi: 10.1192/bjp.112.483.211-a.

Baqi, M. F. A. (2013) Mu'jam Mufahras li Alfadz alQuran. Kairo: Darul Hadis.
Beed, C. and Beed, C. (2010) 'Theology as a Challenge to Social Science', Aejt, 16(August), pp. 1-32.

Chaeruddin, B. (2016) 'Ilmu-IImu Umum dan IImuIImu Keislaman (Suatu Upaya Integrasi)', Jurnal Inspiratif Pendidikan, 5(1), pp. 209-222.

Ditjen PKH (2017) Subsektor Peternakan 2017 Edisi : 02 / tenaker / 08 / 2017. Available at: http://ditjenpkh.pertanian.go.id/userfiles/File/Te naga_Kerja2.pdf?time=1505371480815.

Hidayatullah, S. (2018) 'Konsep Ilmu Pengetahuan Syed Hussein Nashr: Suatu Telaah Relasi Sains Dan Agama', Jurnal Filsafat, 28(1), p. 113. doi: 10.22146/jf.30199.

Janah, N. (2018) 'Pendekatan Normativitas dan Historisitas serta Implikasinya dalam Perkembangan Pemikiran Islam', Cakrawala: Jurnal Studi Islam, 13(2), pp. 102-119. doi: 10.31603/cakrawala.v13i2.2331.

Lajnah Pentashihan al-Quran (2017a) 'Tafsir al-Quran Tematik 4'. Jakarta: Kamil Pustaka.

Lajnah Pentashihan al-Quran (2017b) Tafsir al-Quran Tematik 8. 1st edn. Jakarta: Kamil Pustaka.

Muslih, M. (2016) 'Al-Qur'an dan Lahirnya Sains Teistik', Tsaqafah, 12(2). doi: 10.21111/tsaqafah.v12i2.756.

Novayani, I. (2017) '4. Islamisasi Ilmu Pengetahuan Menurut Pandangan Syed M. Naquib Al-Attas Dan Implikasi Terhadap Lembaga Pendidikan International Institute of Islamic Thought Civilization (Istac)', I(1), pp. 74-89.

Safitri, L. (2016) 'Tujuan Pendidikan Islam', Tsamrah al-Fikri, Volume 10(Issue 1), pp. 1-8. Available at: http://riset-iaid.net/index.php/TF/article/view/2.

Shihab, M. Q. (2000a) 'Tafsir al-Mishbah: Pesan, Kesan dan Keserasian al-Quran 1'. Ciputat: Lentera Hati.

Shihab, M. Q. (2000b) 'Tafsir al-Mishbah: Pesan, Kesan dan Keserasian al-Quran 2'. Ciputat: Lentera Hati.

Shihab, M. Q. (2000c) Tafsir al-Mishbah: Pesan, Kesan dan Keserasian al-Quran 4. Ciputat: Lentera Hati. 